\title{
Active immunization of the cow against oestradiol-17及
}

\author{
T. E. Martin*, D. M. Henricks, J. R. Hill, Jr and N. C. Rawlings $\dagger$ \\ Departments of Animal Science and Food Science, Clemson University, Clemson, \\ South Carolina 29631, U.S.A.
}

\begin{abstract}
Summary. Six beef heifers were immunized over a 4-month period with an oestradiol$17 \beta-B S A$ conjugate in Freund's adjuvant. There was an interference with oestrus in the treated heifers; 2 ceased to exhibit oestrus, one exhibited one oestrus and three exhibited oestrus after Day 47 of treatment. The control heifers treated with Freund's adjuvant had normal oestrous cycles. The antiserum titre rose in all treated heifers and attained its highest level in the 2 animals in which oestrus did not recur. The temporal changes in plasma $\mathrm{LH}$, progesterone and oestradiol were normal during the pretreatment period, but became abnormal during the 120 days after immunization. Although plasma oestradiol- $17 \beta$ rose at the expected time of oestrus after treatment, it was apparently effectively neutralized by the antiserum induced by treatment as evidenced by the absence of an LH surge. Plasma progesterone levels fell to baseline and remained low, indicating lack of formation of corpora lutea.
\end{abstract}

\section{Introduction}

The temporal pattern of changes in plasma concentrations of $\mathrm{LH}$, oestrogens and progesterone during the oestrous cycle of the cow is well established (Henricks, Dickey \& Niswender, 1970; Henricks, Dickey \& Hill, 1971), but the meaning of many of the changes observed is still not clear. Active and passive immunization studies of hormones have proved to be useful for elucidation of the functions of individual hormones in sheep (Pant \& Rawlings, 1973; Fairclough, Smith \& Peterson, 1976). In the present study cows were actively immunized against an oestradiol-17 $\beta$-bovine serum albumin conjugate to investigate the progressive endocrine and physiological changes associated with the neutralization of circulating oestradiol-17 $\beta$.

\section{Materials and Methods}

Ten Hereford heifers which had exhibited 3 normal oestrous cycles (17-23 days) were randomly allotted to 2 groups. On Day 2 of an oestrous cycle 6 heifers (Nos 1, 24, 28, 52 and 88) were injected subcutaneously, in multiple sites along the back, with $2 \mathrm{ml}$ of an emulsion of $0.9 \%(\mathrm{w} / \mathrm{v}) \mathrm{NaCl}$ and Freund's complete adjuvant containing $2 \mathrm{mg}$ of an oestradiol-17ß-6-carboxymethoxime-BSA conjugate. Four heifers (Nos 2, 16, 25 and 60) served as controls and were similarly injected with emulsion alone. A booster injection was given 10 days later (Day 12 of the cycle) and subsequently at monthly intervals for 4 months.

Treatment and bleeding schedules for both groups of cows are shown in Text-fig. 1. The experiment was divided into three periods: Period $I=$ pretreatment period, Period $I I=$ initial treatment (Days 0-23), and Period III = final treatment (Days 24-50). Day 0 is the day of oestrus of the treatment cycle. All heifers were bled every 4 days by jugular venepuncture, starting during the oestrous cycle before treatments commenced and continuing for 4 months or until the heifer returned to

* Present address: Department of Animal Science, Mississippi State University, Mississippi, U.S.A.

$\dagger$ Present address: Department of Veterinary Physiological Sciences, University of Saskatchewan, Saskatoon, Saskatchewan, Canada S7N 0W0. 
oestrus (as did Nos 1,24 and 88). At the time of expected oestrus, samples were taken every 6h. Ovarian activity was assessed by means of rectal palpation of all heifers on Day 50. Laparotomies were performed on all treated heifers on Day 100 to observe ovarian structure.

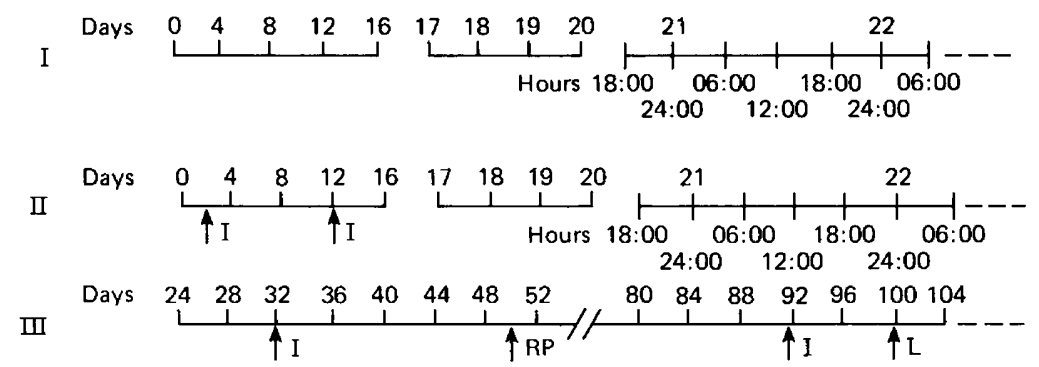

Text-fig. 1. Scheme of the treatment and bleeding times for heifers in the pretreatment (I), initial treatment (II) and final treatment (III) periods. Blood samples were collected on the days and at the hours shown; $I=$ time of injection of oestradiol-17 $\beta$-protein conjugate; $\mathrm{RP}=$ rectal palpation; $\mathrm{L}=$ laparotomy.

\section{Hormone assays}

$L H$. Plasma $\mathrm{LH}$ was measured by a double-antibody radioimmunoassay system as previously described (Henricks et al., 1970). Duplicate determinations of all samples were carried out on $200 \mu \mathrm{l}$ aliquots. The sensitivity limit of the assay was $9 \pm 4 \mathrm{pg}$ (s.e.m., $n=16$ ) per assay tube. A sample from a plasma pool was analysed at 3 different volumes in each assay $(50,100$ and $200 \mu l)$ giving concentrations of $\mathbf{L H}$ per assay tube of $0 \cdot 88-3.55 \mathrm{ng}$. The coefficient of variation (C.V.) of this pool was $5 \cdot 1 \%(n=22)$ between assays and $3 \cdot 2 \%(n=4)$ within assays.

Progesterone. The radioimmunoassay for plasma progesterone has been described in detail (Rawlings, Kennedy, Chang, Hill \& Henricks, 1977). Progesterone was extracted from plasma with petroleum ether and the extracts assayed directly by using an antiserum specific for progesterone (HD-RC-4/10/73). The percentage cross-reaction of the antiserum with eight other steroids was less than $1 \%$ (Rawlings et al., 1977). Duplicate determinations were made on all plasma samples and all values were corrected for procedural losses. The sensitivity limit of the assay was $20.0 \pm 0.5$ (s.e.m., $n=15$ ) pg per assay tube. Samples of various plasma pools were assayed repeatedly covering the range of 0.04 to $1.88 \mathrm{ng}$ progesterone per assay tube. The mean C.V. for the analysis of these pools was $13 \cdot 8 \%(n=38)$ within assays and $16 \cdot 4 \%(n=24)$ between assays.

Oestradiol-17 $\beta$. The radioimmunoassay was that described by Rawlings et al. (1977). Oestradiol$17 \beta$ was extracted from plasma with diethyl ether and the extracts assayed with an antiserum that showed a $9 \%$ cross-reaction with oestrone and less than $0.1 \%$ with oestriol, oestradiol- $17 \alpha$ and 6 other steroids. Duplicate determinations were made for all samples on $4 \mathrm{ml}$ aliquots of plasma and all values were corrected for procedural losses. The assay sensitivity limit was $6.0 \pm 0.9 \mathrm{pg}$ per assay tube $(n=$ 30). Repeated analysis of samples of plasma pools with concentrations in the range of 13.7 to $110.0 \mathrm{pg}$ oestradiol-17 $\beta$ per assay tube resulted in a mean C.V. of $8.2 \%(n=74)$ within assays and of $7 \cdot 6 \%$ $(n=38)$ between assays. The antiserum titre was measured periodically in the treated heifers and one control heifer (No. 60) by incubating aliquots of the plasma ( $1: 100$ dilution) with $34 \mathrm{pg}\left[{ }^{3} \mathrm{H}\right]$ oestradiol$17 \beta$ (sp. act. $98 \mathrm{Ci} / \mathrm{mmol}$ : New England Nuclear Corp.).

\section{Results}

The 4 control heifers continued to show regular oestrous cycles throughout the experiment. The mean cycle length was $21 \pm 2$ days (s.e.m.). Five of the 6 immunized heifers failed to return to oestrus at the expected time, i.e. after the second injection on Day 16, and two of them(Nos 28 and 52) did not exhibit oestrus during the 4-month observation period. Heifers 1, 24 and 88 returned to oestrus on 
Days 53, 48 and 47, respectively, after their last oestrus. One immunized heifer (No. 65) exhibited oestrus once during the initial treatment period (Day 21), then failed to cycle for the remainder of the experiment.

Rectal palpation on Day 50 and laparotomy on Day 100 revealed the existence of large follicular cysts (4-8 cm diameter) in the ovaries of Heifers 28 and 52, the animals that failed to exhibit oestrus during the 4-month observation period. Of the other 4 immunized heifers, Nos 24, 65 and 88 had ovaries with cystic and luteinized follicles, while the ovaries in Heifer 1 were normal.

Table 1. The percentage binding of oestradiol-17 $\beta$ by aliquots of plasma from heifers immunized against an oestradiol-17 $\beta$-protein conjugate

\begin{tabular}{crrrrrrr}
\hline $\begin{array}{c}\text { Time from } \\
\text { initial injection } \\
\text { (days) }\end{array}$ & 28 & 52 & 1 & 24 & 88 & 65 & 60 \\
\cline { 2 - 7 } & 3 & 3 & 3 & 3 & 3 & 3 & 3 \\
-3 & 4 & 3 & 3 & 4 & 3 & 3 & 2 \\
0 & 3 & 4 & 4 & 3 & 4 & 3 & 3 \\
4 & 22 & 22 & 5 & 8 & 6 & 4 & 5 \\
16 & 54 & 36 & 12 & 16 & 14 & 14 & 4 \\
25 & 77 & 53 & 16 & 27 & 21 & 24 & 4 \\
50 & 101 & 81 & - & - & - & 52 & 2 \\
100 & 98 & 93 & - & - & - & 64 & 3 \\
125 & 96 & 87 & - & - & - & - & 3 \\
150 & & & & & & & \\
\hline
\end{tabular}

The values are the percentage of total $\left[{ }^{3} \mathrm{H}\right]$ oestradiol-17 $\beta$ bound to the antiserum which was used at an initial dilution of $1: 100$. Day 0 represents the day of oestrus of the cycle when treatment was started with injections on Days 2 and 12. Heifers 1, 24 and 88 exhibited oestrus by Day 50 and were not bled thereafter.

The oestradiol antibody titres of the immunized heifers and a control heifer are shown in Table 1 . Percentage binding did not exceed the levels seen in control heifers until after the second injection of the oestradiol-protein conjugate on Day 12, but then the titre rose steadily. The two heifers (Nos 28 and 52) having large follicular cysts and becoming anoestrous for the duration of the experiment had the highest antibody titres. Antibody titres were not determined for Heifers 1, 24 and 88 after Day 50 because they had by then exhibited oestrus.

Changes in the plasma concentrations of $\mathrm{LH}$, oestradiol-17 $\beta$ and progesterone in the four control heifers were similar to those reported by Henricks et al. (1970) and Henricks et al. (1971). The changes in the plasma concentrations of these hormones during the pre-, initial and final treatment periods for the 6 immunized heifers and one control heifer are shown in Text-fig. 2. The six immunized heifers exhibited normal cyclic changes of these hormones during the pretreatment cycle. Progesterone concentration fell to baseline level 4-5 days before oestrus, then oestradiol-17 $\beta$ began to rise, reaching a peak just before oestrus. An LH peak occurred 6-18 h after the onset of oestrus. The treated heifers were injected 2 days after oestrus. The plasma progesterone concentration rose from baseline to peak levels (peak range $=5 \cdot 0-9.7 \mathrm{ng} / \mathrm{ml}$ ) between Days 4 and 19 and then declined to a baseline level, indicating normal development and regression of a corpus luteum (CL). After treatment the normal rise in plasma oestradiol-17 $\beta$ concentration occurred between Days 17 and 22 but the preovulatory increase in plasma LH was absent. In Heifer 28 , oestradiol- $17 \beta$ rose to a peak of $14.7 \mathrm{pg} / \mathrm{ml}$ on Day 20 and in Heifer 52 it rose to $13.4 \mathrm{pg} / \mathrm{ml}$ on Day 22, but in none of the treated cows, not even No. 65 , did plasma LH rise above $4 \mathrm{ng} / \mathrm{ml}$. Heifer 65 exhibited oestrus on Day 23 and on Day 22 the plasma oestradiol-17 $\beta$ was $16.4 \mathrm{pg} / \mathrm{ml}$. Although this concentration is similar to the peak levels detected in Heifers 28 and 52, which did not show oestrus, the antibody titre in Heifer 65 at this time was much lower. 

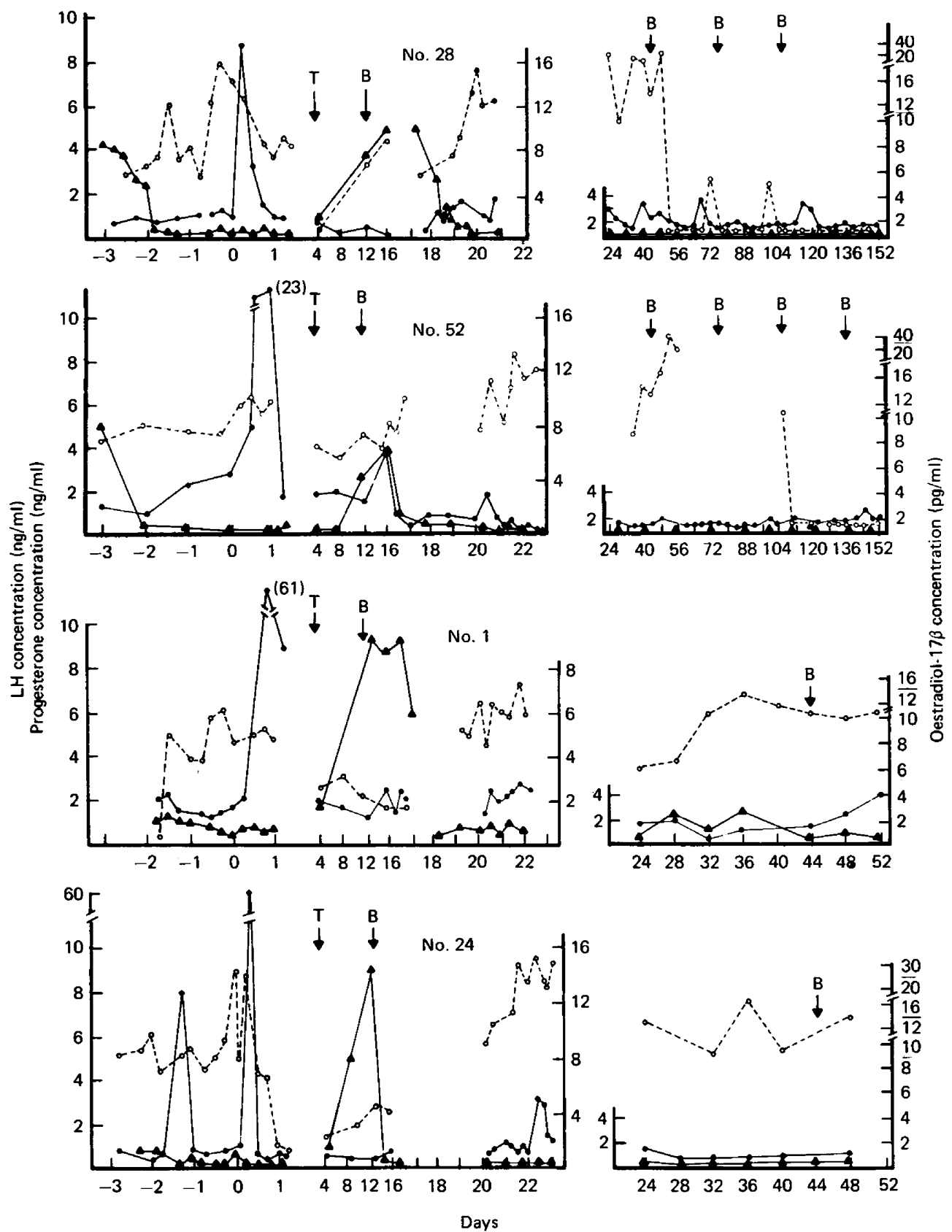

After Day 22 (the final treatment period) plasma progesterone concentrations remained at baseline levels until blood sampling of each treated animal was stopped, a period lasting from 50 to 150 days. Plasma oestradiol-17 $\beta$ remained at least higher, and in most cases considerably higher, than levels at pro-oestrus $(12-20 \mathrm{pg} / \mathrm{ml})$ in all heifers, except No. 28 , until the end of the experiment. In Heifer 28 the level was high until Day 52, then decreased greatly. On the basis of the blood sampling schedule followed in this experiment, plasma $\mathrm{LH}$ concentrations changed little during this period. In 3 treated heifers the LH concentrations did not rise above $2 \mathrm{ng} / \mathrm{ml}$; in the other 3 heifers, the LH . concentration was more variable but did not rise above $4 \mathrm{ng} / \mathrm{ml}$. 

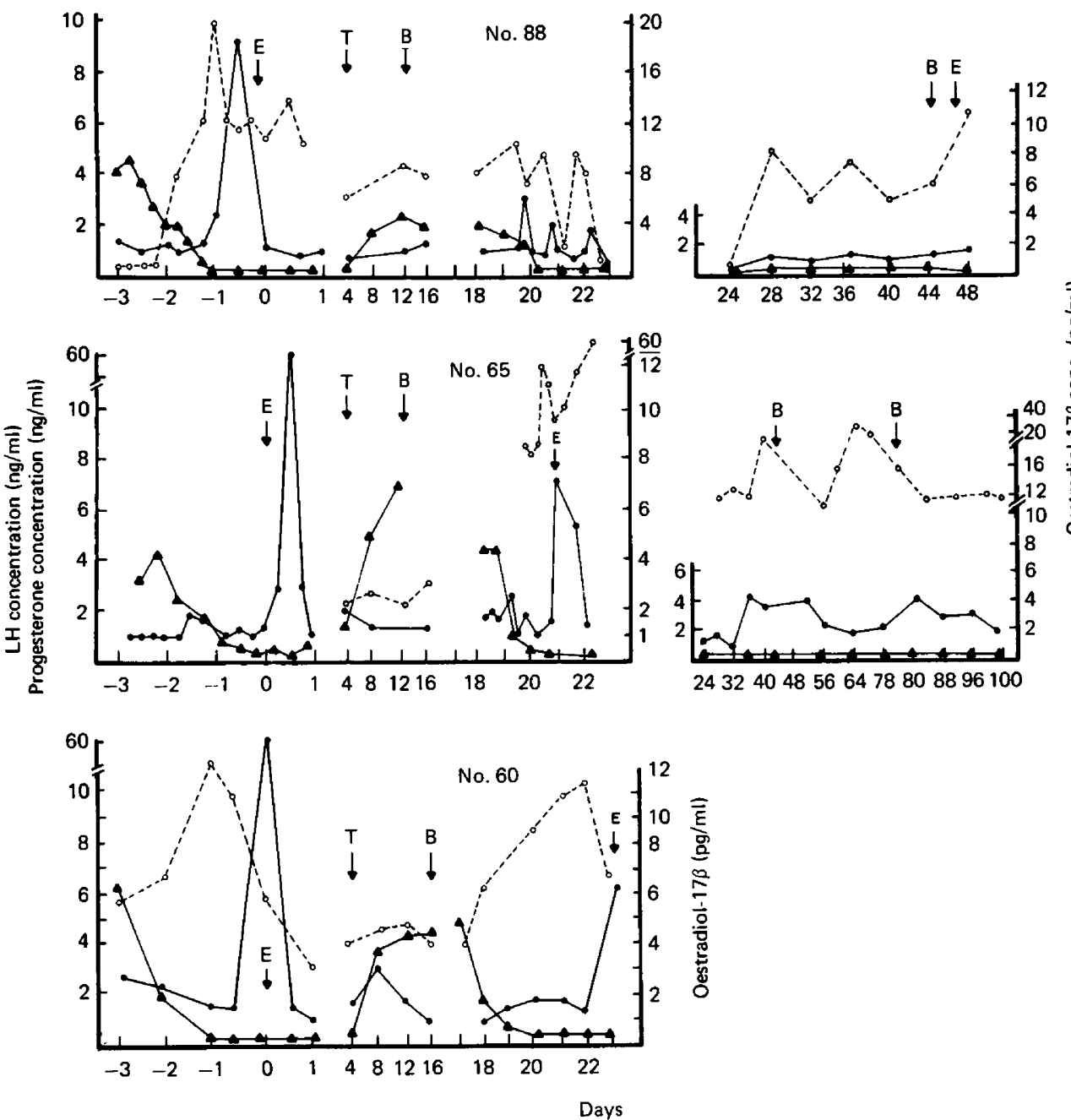

Text-fig. 2. Plasma concentrations of progesterone $(\Delta)$, oestradiol-17ß $(0)$ and $L H(\bullet)$ during the pretreatment (Days -3 to +1 ), initial treatment (Days 4 to 23) and final treatment (from Day 24: note the scale change) periods of heifers treated with an oestradiol-17 $\beta$-protein conjugate in Freund's adjuvant (Nos 28, 52 , 1, 24, 88 and 65) or with Freund's adjuvant alone (No. 60). T= first injection; B= booster injection; $\mathrm{E}=$ oestrus.

\section{Discussion}

Normal CL function occurred during the oestrous cycle in which the oestradiol-17 $\beta$-protein conjugate was administered. Also, neither the magnitude nor the temporal pattern of the elevated oestradiol-17 $\beta$ level was different after treatment from that occurring before the pretreatment oestrus in the immunized cows, or before oestrus in the control cows. The fact that the expected preovulatory surge in plasma $\mathrm{LH}$ and oestrus did not occur suggests that the elevated oestradiol-17 $\beta$ did not exert its normal effect, presumably because a significant portion of the hormone was bound to antibodies in a neutralized form as indicated by the titres obtained (Table 1). The assay used in this study measures total non-covalently bound oestradiol $-17 \beta$ and therefore does not discriminate between the antibodybound and free forms. Thus, this study confirms in the cow the findings of others with the ewe (Scaramuzzi, Tillson, Thorneycroft \& Caldwell, 1971) that a pro-oestrous rise in the free oestradiol-17 $\beta$ 
is essential for the occurrence of behavioural oestrus and the preovulatory LH surge. The neutralization of the oestrogen by the ant ibodies induced by immunization with an oestradiol-protein conjugate resulted in an interruption of reproductive cyclicity in the treated heifers. The elevation in the plasma level of total oestrogen may be due to a decreased rate of catabolism of the oestrogen (Longscope, 1970 ) and/or to an increase in the gonadotrophic stimulation of oestrogen secretion in response to depressed free oestradiol-17 $\beta$ levels. Pant \& Rawlings (1973) reported elevated plasma LH levels in the ewe after immunization with an oestrogen-protein conjugate and the cessation of oestrous cycles was obtained by Pant \& Rawlings (1973) and Scaramuzzi (1975) after active and passive immunization, respectively.

The gradual rise in antibody titre in parallel with the gradual appearance of increased variability in plasma concentration of LH probably reflects a gradual withdrawal of a positive feedback effect of oestradiol-17 $\beta$ on $\mathrm{LH}$ secretion via a lack of binding of the oestrogen by the receptors in the preoptic anterior hypothalamic area and hypothalamus which stimulates the synthesis and/or secretion of LH-RH.

We thank Dr G. D. Niswender for the LH antiserum (GDN-15), Dr Hilary Dobson for the progesterone antiserum (HD-RC-4/10/73), and Dr L. E. Reichert for gifts of highly purified bovine LH (LER-1072-2). The paper is Technical Contribution No. 1462 of the South Carolina Agricultural Experiment Station and is published with the approval of the Director.

\section{References}

Fairclough, R.J., Smith, J.F. \& Peterson, A.J. (1976) Passive immunization against oestradiol-17 $\beta$ and its effect on luteolysis, oestrus and ovulation in the ewe. $J$. Reprod. Fert. 48, 169-171.

Henricks, D.M., Dickey, J.F. \& Niswender, G.D. (1970) Serum luteinizing hormone and plasma progesterone levels during the estrous cycle and early pregnancy in cows. Biol. Reprod. 2, 346-351.

Henricks, D.M., Dickey, J.F. \& Hill, J.R. (1971) Plasma estrogen and progesterone levels in cows prior to and during estrus. Endocrinology 89, 13501355.

LONGSCOPE, C. (1970) The use of antibodies as a tool in studies in reproductive physiology. In Immunological Methods in Steroid Determination, pp. 222-240. Eds F. G. Peron \& B. V. Caldwell. AppletonCentury-Crofts, New York.
Pant, H.C. \& Rawlings, N.C. (1973) The effect of active immunization against oestradiol-17 $\beta$ on plasma gonadotrophin concentrations in sheep. J. Reprod. Fert. 35, 610-611.

Rawlings, N.C., Kennedy, S.W., Chang, C.H., Hill, J.R. \& HenRicks, D.M. (1977) The onset of seasonal anestrous in the ewe. J. Anim. Sci. 44, 791-797.

SCARAmuzzI, R.J. (1975) Inhibition of oestrous behaviour in ewes by passive immunization against oestradiol-17ß. J. Reprod. Fert. 42, 145-148.

Scaramuzzi, R.J., Tillson, S.A., Thorneycroft, I.H. \& CALDWELL, D.S. (1971) Action of exogenous progesterone and estrogen on behavioral estrus and luteinizing hormone levels in the ovariectomized ewe. Endocrinology 88, 1184-1189.

Received 23 December 1977 